\title{
Correlation of VEGF production with IL1 $\alpha$ and IL6 secretion by human pituitary adenoma cells
}

\author{
S A Borg ${ }^{1}$, K E Kerry ${ }^{1}$, J A Royds ${ }^{2}$, R D Battersby ${ }^{3}$ and T H Jones ${ }^{1,4}$ \\ ${ }^{1}$ Hormone and Vascular Group, Academic Unit of Endocrinology, Division of Genomic Medicine, University of Sheffield Medical School, Beech Hill Road, \\ Sheffield S1O 2RX, UK, ${ }^{2}$ Department of Pathology, University of Otago, Otago, New Zealand, 'Department of Neurosurgery, Royal Hallamshire Hospital, \\ Sheffield S1O 2RX, UK, ${ }^{4}$ Centre for Diabetes and Endocrinology, Barnsley District General Hospital, Gawber Road, Barnsley S75 2EP, UK
}

(Correspondence should be addressed to DrT H Jones; Email: hugh.jones@bdgh-tr.trent.nhs.uk)

\begin{abstract}
Objectives: Vascular endothelial growth factor (VEGF) is considered to be the most important angiogenic factor involved in the neovascularisation of solid tumours. Regulatory molecules include cytokines and growth factors. Interleukin (IL) 1 and IL6 have both been shown to regulate VEGF levels in a variety of tissues. The role of cytokines in the pathogenesis of pituitary tumours remains unclear. We have examined the expression of VEGF and its relationships with IL1 and IL6 in the human pituitary tumour cell line HP75 and a series of human pituitary tumours. We have also looked at the relationship of tumour volume and invasive status to VEGF secretion.

Methods: Surgically resected tumours were routinely cultured in single-cell suspension at 200 K/well (standard unit for culture of dispersed primary pituitary adenoma cells). We measured VEGF, IL1 $\alpha$ and IL6 levels by ELISA. Tumour volume and invasion grade were assessed by preoperative magnetic resonance imaging.

Results: VEGF was detected in conditioned medium of HP75 cells $(900 \pm 52 \mathrm{pg} / \mathrm{ml})$ and in $82 \%$ of tumours tested (range 26-16464 pg/ml). Tumour volume and secretion of VEGF were significantly associated with levels of IL6 (volume, $P=0.056$; VEGF, $P<0.001$ ( $P$ values based on Spearman's test)) and IL1 $\alpha$ produced (volume, $P<0.005$; VEGF, $P<0.001$ ). Invasive tumours showed a higher basal secretion of VEGF that that of the non-invasive type; however, this difference was not significant. Addition of exogenous IL1 $\alpha$, but not IL6, significantly increased VEGF production. Conclusions: The significant associations between VEGF and the levels of IL6 and IL1 $\alpha$ suggest an important role for these cytokines in the development of these tumours.
\end{abstract}

European Journal of Endocrinology 152 293-300

\section{Introduction}

Vascular endothelial growth factor (VEGF) is known to be a potent mitogen for vascular endothelial cells and an inducer of physiological and pathological angiogenesis (1). Angiogenesis, the growth of new capillaries from pre-existing blood vessels, is essential for tumours to grow beyond a few millimetres in diameter $(2,3)$. VEGF is also essential for normal developmental vasculogenesis and angiogenesis, as both null $(-/-)$ and heterozygote $(+/-)$ animals are embryonic lethals $(4,5)$.

IL6 is known to be expressed in the normal pituitary gland by folliculostellate (FS) cells, but not secretory cells and all subtypes of human pituitary adenomas. First demonstrated by Jones et al., secretion of IL6 by these tumours was seen to be independent of subtype (6), as confirmed by IL6 mRNA detection $(7,8)$. The production in the normal gland is believed to be by FS cells (9); however, in pituitary adenomas, it is the tumour cells which are the source of production (10). The role of other cytokines released by pituitary adenomas has received less attention. Expression of IL1 $\alpha$ and $\beta$ has been demonstrated only by RT-PCR, with 3 of 17 tumours positive for IL1 $\alpha$ and 6 of 17 positive for the $\beta$ isoform (8).

The role of cytokines in the pathogenesis of human pituitary tumours has proven difficult to elucidate, as primary cultures from most pituitary tumours do not display significant growth to allow extensive study. Therefore, in addition to our use of primary tissue, we have used the recently developed HP75 cell line, the only established human pituitary tumour cell line (11). This cell line, derived from a clinically non-functioning plurihormonal adenoma, was transfected with the SV40 virus, and it retains a number of differentiated functions, including chromogranin A expression and positive staining for luteinising hormone (LH).

In normal tissues, vascular quiescence is maintained by the dominant influence of endogenous angiogenesis inhibitors over angiogenic stimuli, whereas tumour angiogenesis is induced by increased secretion of angiogenic factors and/or by downregulation of angiogenesis inhibitors (12). VEGF is regarded as the major angiogenic factor during epithelial carcinogenesis in a large 
number of human cancers and metastases $(13,14)$. It is ubiquitously expressed in many human tumours, including those of the lung (15), breast (16) and ovary (17), and in glioblastoma multiforme (18). The key regulator of VEGF expression is hypoxia $(19,20)$; however, a range of cytokines and growth factors have been shown to regulate and correlate with VEGF expression. Interleukin (IL) $1 \alpha / \beta$ stimulates production of VEGF in a diverse range of cell types, including human cultured synovial fibroblasts (21), peripheral blood mononuclear cells (22), vascular smooth muscle cells (23) and cardiac myocytes (24), and also in rat ovary cells (25). In parallel with this, another cytokine seen to regulate VEGF in a variety of tissues is IL6. It has been suggested that IL6 may induce angiogenesis not only through its effects on VEGF expression but also by its direct stimulation of the motility of cells such as endothelial cells $(26,27)$. In rat skeletal muscle myoblasts and glioma cells, Cohen et al. found that IL6 increases VEGF mRNA expression by levels comparable to those seen with hypoxia (28). Addition of exogenous IL6 to a cervical cancer cell line in vitro has also been found to show a time- and dose-dependent increase of VEGF expression (29). While Salgado et al. found that exogenous IL6 showed no effect on VEGF levels, removing basally secreted IL6 by a neutralising antibody significantly lowered the VEGF secretion by a human megakaryoblastic cell line (30). A number of studies measuring the basal levels of VEGF and IL6 have been conducted; a positive correlation has been observed between serum levels of IL6 and VEGF in patients with advanced metastatic cancer (31). More recently, serum levels of IL6 and VEGF have shown a positive correlation in patients with breast and gastric carcinomas (32-34).

The presence of VEGF has been widely reported in human pituitary adenomas and various pituitary cell lines (35-38). However, the factors regulating its expression in these tumours have not been widely investigated. In the pituitary FS cells, IL6 and glucocorticoids, which are regulators of IL6 secretion, were observed to increase and decrease VEGF secretion respectively (39). A more comprehensive study of the presence and regulation of VEGF secretion by Lohrer et al. looked at primary culture of human pituitary adenomas and four rat and murine pituitary cell lines (35). They detected VEGF secretion by the majority of the pituitary adenomas and all the cell lines. VEGF levels were enhanced in some of the primary tumours by tumour growth factor (TGF) $\alpha$, pituitary adenylate cyclase activating polypeptide (PACAP) and 17 $\beta$-oestradiol, and inhibited by the glucocorticoid, dexamethasone. The pituitary adenoma cell lines were responsive only to dexamethasone, and this agent inhibited VEGF secretion. The TtT/GF FS line showed the greatest responsiveness to the stimuli, and basal values were augmented by a wide range of factors, including IL6, PACAP, TGF $\alpha$, insulin-like growth factor (IGF)-I and the somatostatin analogue, octreotide (35).
The generation of a direct arterial supply during neovascularisation has important consequences for pituitary tumour cells, as it not only allows tumour expansion but also uncouples the adenoma cells from the portal blood system and thus from hypothalamic control $(40,41)$. VEGF is considered to be the most important angiogenic factor involved in the neovascularisation of solid tumours. Understanding the regulation of VEGF secretion will provide an important insight into the development of these tumours. We have investigated the expression of VEGF and its regulation in a series of 59 human pituitary adenomas and in the HP75 cell line. HP75, an available human pituitary tumour cell line, retains some differentiated functions and is known to secrete IL6 (42). Focusing our attention on the cytokines IL1 $\alpha$ and IL6 and their relationship to VEGF expression, we have also examined the relationship of VEGF with tumour invasive status and volume.

\section{Materials and methods}

\section{Cell culture}

HP75 cells were routinely cultured in DMEM (BioWhittaker/Cambrex, East Rutherford, NJ, USA) containing $15 \%$ horse serum (TCS Cellworks, Buckingham, UK) and $2.5 \%$ foetal calf serum (FCS) (Gibco BRL, Invitrogen, Paisley, UK). For growth and stimulatory studies, HP75 cells were plated in 24-well plates at $30 \mathrm{~K} /$ well in DMEM containing $2 \%$ foetal calf serum. After $24 \mathrm{~h}$, the medium was changed, and test substances were added where required. After $72 \mathrm{~h}$, conditioned medium was removed and stored at $-80^{\circ} \mathrm{C}$. All experiments were conducted in triplicate wells and repeated at least four times.

Human pituitary adenomas removed in routine transphenoidal surgery were prepared and dispersed for primary culture. The tissue was finely minced with a scalpel to maximise the tissue surface area for enzymatic digestion and incubated with dispase (Roche) $(2.4 \mathrm{U} / \mathrm{ml})$ in a shaking water bath at $37^{\circ} \mathrm{C}$ for from $30 \mathrm{~min}$ to $3 \mathrm{~h}$, depending on the level of mucus present. Tissue dispersal was completed mechanically with needles of increasing gauge $(19-25 \mathrm{~g})$. Cells were spun at 1500 r.p.m. for $8 \mathrm{~min}$, and the supernatant was poured off. Cells were resuspended, and hypotonic lysis was performed as described by Atkin et al. (43). Cells were counted with a haemocytometer and plated at $200 \mathrm{~K} /$ well into 24-well plates in $1 \mathrm{ml}$ medium composed of Med199 (BioWhittaker) with 10\% FCS, Fungizone $(1.25 \mu \mathrm{g} / \mathrm{ml})$ (BioWhittaker) and gentamicin (Hoechst, Roussel Laboratories, Cambridge, UK) $(50 \mu \mathrm{g} / \mathrm{ml})$. After $96 \mathrm{~h}$, the medium was removed and stored, and it was replaced with Med199 containing the above ingredients but with only $2 \%$ FCS. Next, the test substances were added, and the cells were incubated for a further $72 \mathrm{~h}$, 
after which the conditioned medium was removed and frozen.

\section{Alamar Blue}

Cell growth was measured with Alamar Blue (Serotec, Oxford, UK). Alamar Blue was added to equal $10 \%$ of culture volume and incubated for $5.5 \mathrm{~h}$ at $37^{\circ} \mathrm{C}$; absorbance was then measured at 570 and $600 \mathrm{~nm}$. All values are expressed as optical density (OD).

\section{ELISA}

IL6 was measured from cell-culture supernatants by ELISA with the IL6 Eli-pair antibody kit (IDS Ltd, Tyne and Wear, UK). Briefly, 96 well plates were coated with capture antibody and allowed to incubate overnight at $4^{\circ} \mathrm{C}$. Following washing and blocking of non-specific binding sites samples and standards (appropriately diluted) were added and then co-incubated with biotinylated anti-IL6 antibody for $1 \mathrm{~h}$ at room temperature. After further washing, the plates were incubated with horseradish peroxidase strepavidin (HRP-Strep) followed by 3,3',5,5'-tetramethylbenzidine (TMB) for $8-10 \mathrm{~min}$. The reaction was stopped on addition of $1 \mathrm{M} \mathrm{H}_{2} \mathrm{SO}_{4}$, and absorbance was read at 450 and $630 \mathrm{~nm}$. The sensitivity range was $6.25-$ $200 \mathrm{pg} / \mathrm{ml}$. The interassay variation was $\pm 5.4 \%$ and the intra-assay variation was $\pm 2.8 \%$.

VEGF was measured by a commercially available ELISA kit (AMS Biotechnology, Abingdon, UK), according to the manufacturer's instructions. The detection range was $20-2500 \mathrm{pg} / \mathrm{ml}$. The intra-assay variation was $\pm 8.9 \%$; that of the interassay was $\pm 11.1 \%$.

IL1 $\alpha$ was measured by a commercially available ELISA kit (IDS), according to the manufacturer's instructions. The detection range was $10-1000 \mathrm{pg} / \mathrm{ml}$. The intraassay variation was $\pm 3.9 \%$, and the interassay variation was $7.3 \%$.

\section{Radiology}

The preoperative magnetic resonance imaging (MRI) scans of patients were reviewed by a neuroradiologist to determine their invasive status and volume. As we assumed the tumour to be spherical or egg-shaped, its volume was calculated by the formula for determining spherical volume, $\mathrm{v}=4 / 3 \pi\left[\left(\mathrm{r}_{1}+\mathrm{r}_{2}+\mathrm{r}_{3}\right) / 3\right]^{3}$, where $v$ is tumour volume in $\mathrm{mm}^{3}$, and $r_{1}, r_{2}$ and $r_{3}$ are tumour height, and transverse and anteroposterior diameters respectively in $\mathrm{mm}$. Invasive status was classified by the modified method of Hardy (44), placing adenomas in one of four grades, grades 1 and 2 showing no invasion, and grades 3 and 4 showing invasive activity.

\section{Statistical analysis}

All data groups were tested for normality by the onesample Kolmogorov-Smirnov test, with subsequent analysis by either parametric or non-parametric tests as appropriate. Correlations between two variables showing non-normal distribution were assessed by the non-parametric Spearman correlation test. Comparison between two groups showing a normal distribution was made by Student's $t$-test and for nonparametric data by the Mann-Whitney U test.

\section{Results}

\section{VEGF}

VEGF levels were measured in the conditioned medium from a total of 59 tumours. Of these, 32 were null-cell adenomas, seven were growth hormone (GH)-secreting tumours, seven were adrenocorticotrophin hormone (ACTH)-secreting tumours (two silent), nine were silent gonadotrophinomas, one was a prolactinoma and three were plurihormonal tumours (GH/prolactin (PRL), $\mathrm{PRL} / \mathrm{GH} /$ thyroid-stimulating hormone (TSH) and PRL/GH/TSH/follicle-stimulating hormone (FSH)). Of the 59 tumours examined in this series, $48(82 \%)$ secreted measurable levels of VEGF into the culture medium (Fig. 1). The range of measurable basal secretions was $26-16464 \mathrm{pg} / \mathrm{ml}$. Of these, 29 of 32 null-cell and all the ACTH-producing tumours had measurable levels of VEGF. Seven of the nine gonadotrophinomas and five of the seven GH secretors also produced VEGE. The one prolactinoma was weakly positive, but neither the bihormonal nor the plurihormonal tumours produced measurable quantities of the protein.

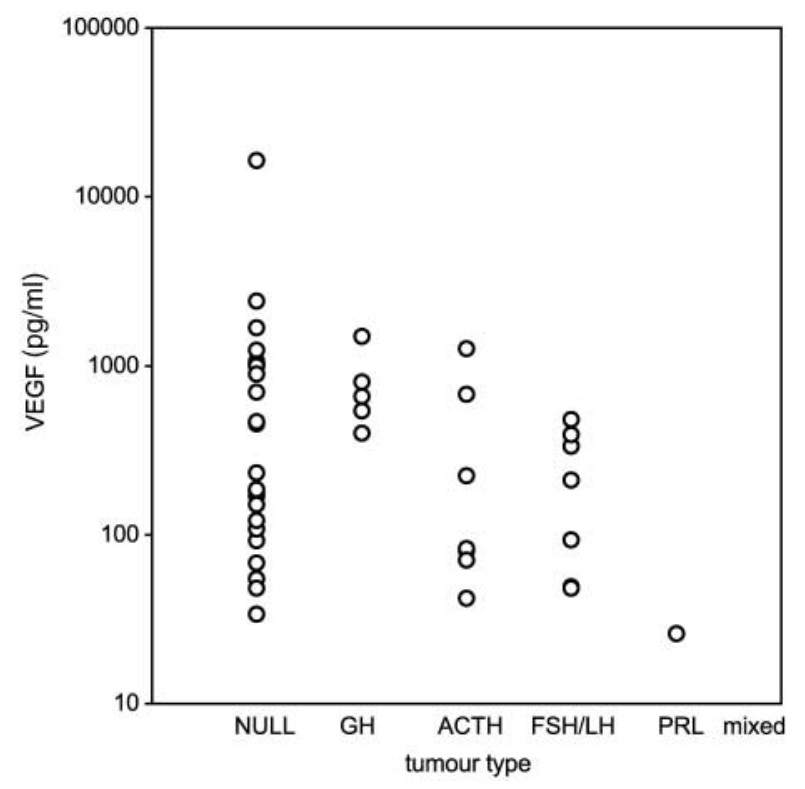

Figure 1 Graph showing the secretion of VEGF $(\mathrm{pg} / \mathrm{ml})$ from cultured pituitary tumour per $200 \mathrm{~K}$ cells. 
We saw constitutive expression of VEGF from HP75 cells with an average secretion of $900 \pm 52 \mathrm{pg} / \mathrm{ml}$ (mean \pm S.E.M.; range: $251-1668 \mathrm{pg} / \mathrm{ml}$ ).

We have reported elsewhere the expression profile of IL $1 \alpha$ and IL6 by the HP75 cell line and primary cultures of human pituitary tumours; therefore, this is not discussed here.

\section{IL6}

The basal levels of IL6 secreted in vitro from the 59 tumours above were assessed. Of the 59 tumours, 58 expressed measurable levels of IL6, ranging from 7 to $1368070 \mathrm{pg} / \mathrm{ml}$. The average basal level of IL6 protein secreted by HP75 cells was measured by ELISA and found to be $6167 \pm 56 \mathrm{pg} / \mathrm{ml}$ (mean \pm S.E.M.; range: $1596-25840 \mathrm{pg} / \mathrm{ml}$ ) over $72 \mathrm{~h}$. It is unclear why there was a high degree of variability in the range of the basal secretions of VEGF and IL6 from HP75 cells.

There was a strong and positive correlation between the basal secretions of IL6 and VEGF by the human pituitary tumours cultured $\left(r^{2}=0.913 ; P<0.0001\right.$; $n=46$ ) (Fig. 2). We also observed a positive association between tumour volume and level of IL6 secreted in vitro at a level very close to significance $(r=0.388$; $n=25 ; P=0.056)$.

\section{IL1 $\alpha$}

The average level of IL1 $\alpha$ secretion from HP75 cells was $51 \pm 6 \mathrm{pg} / \mathrm{ml}$ over $72 \mathrm{~h}$ per $30 \mathrm{~K}$ cells. Fifty-two of the 59 tumours were assayed for IL1 $\alpha$, of which $25(47 \%)$ secreted detectable levels into the culture medium, ranging from 8 to $572 \mathrm{pg} / \mathrm{ml}$.

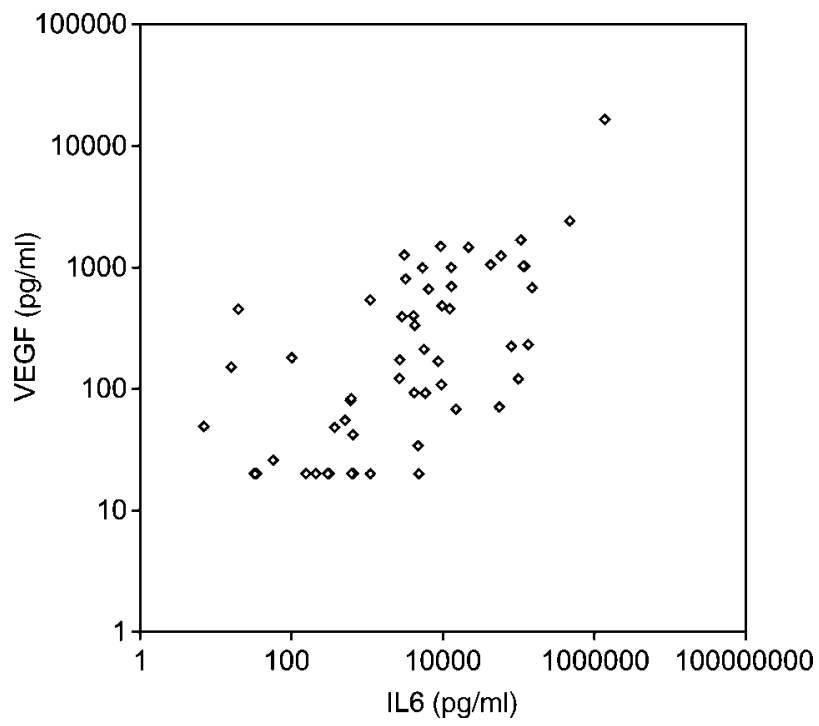

Figure 2 Scatter plot showing a positive correlation between basal IL6 and VEGF secretions by human pituitary adenoma cells in culture $\left(r^{2}=0.913, P<0.0001 ; n=46\right)$.
We saw that tumours that secreted measurable levels of IL1 $\alpha$ secreted significantly greater quantities of VEGF than those that did not $(1363 \pm 697 \mathrm{pg} / \mathrm{ml}, n=24$, vs $172 \pm 52 \mathrm{pg} / \mathrm{ml}, n=27 ; P<0.001)$. These tumours also had significantly larger volumes than non-IL1 $\alpha$ secretors (IL1 secretors, 270.06 $\pm 61.74 \mathrm{ml}, n=11$; IL1 non-secretors, $48.04 \pm 18.25 \mathrm{ml}, n=10 ; P<0.005)$.

\section{Effect of ILI $\alpha$ on VEGF secretion}

HP75 cells and cultured primary tumours were treated with exogenous IL1 $\alpha$, and VEGF release was

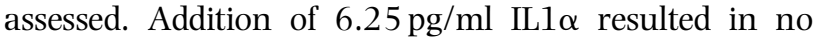
significant change in the level of VEGF secreted by HP75 cells (basal $1055 \pm 60 \mathrm{pg} / \mathrm{ml}$; IL1 $\alpha 6.25 \mathrm{pg} / \mathrm{ml}$ : $858 \pm 19 \mathrm{pg} / \mathrm{ml} ; \quad P>0.05$ ) (Fig. 2). On addition of higher doses of IL1 $\alpha$, that is, 62.5, 625 and $6250 \mathrm{pg} / \mathrm{ml}$, we saw significant increases of $143-149 \%$ in VEGF secretions compared with basal (basal $1055 \pm 60 \mathrm{pg} / \mathrm{ml} ; \quad 62.5 \mathrm{pg} / \mathrm{ml}: \quad 1513 \pm 144 \mathrm{pg} / \mathrm{ml}$, $P=0.002 ; 625 \mathrm{pg} / \mathrm{ml}: 1560 \pm 124 \mathrm{pg} / \mathrm{ml}, P=0.0002$; $6250 \mathrm{pg} / \mathrm{ml}: 1574 \pm 111 \mathrm{pg} / \mathrm{ml} ; P=0.0001$ ) (Fig. 3).

Six primary cultures of pituitary tumours were treated with exogenous IL1 $\alpha$ at doses of 62.5, 625 and $6250 \mathrm{pg} / \mathrm{ml}$, and their VEGF secretions were measured. One tumour produced no measurable levels of VEGF. Two tumours produced significantly increased levels of VEGF (139\% and $173 \%$ ) on stimulation by IL1 $\alpha$ at $6250 \mathrm{pg} / \mathrm{ml}$ (Fig. $4 \mathrm{~A}$, basal $448 \pm 15 \mathrm{pg} / \mathrm{ml} ; 6250 \mathrm{pg} /$ $\mathrm{ml}: \quad 623 \pm 46 \mathrm{pg} / \mathrm{ml}, \quad P=0.02 ; \quad$ Fig. $4 \mathrm{~B}, \quad$ basal $565 \pm 22 ; \mathrm{pg} / \mathrm{ml} \quad 6250: \quad \mathrm{pg} / \mathrm{ml} \quad 975 \pm 146 \mathrm{pg} / \mathrm{ml}$, $P=0.045)$. In another two tumours, we saw an increase in VEGF secretion with doses of IL1 $\alpha$ at 625 and $6250 \mathrm{pg} / \mathrm{ml}$, but statistical significance $\left(^{*}\right)$ was achieved in both tumours only at the $625 \mathrm{pg} / \mathrm{ml}$ dose (Fig. 4C, basal $391 \pm 92 \mathrm{pg} / \mathrm{ml} ; * 625 \mathrm{pg} / \mathrm{ml}$ : $660 \pm 67 \mathrm{pg} / \mathrm{ml}(169 \%), 6250 \mathrm{pg} / \mathrm{ml}: 975 \pm 146 \mathrm{pg} / \mathrm{ml}$; Fig. $4 \mathrm{D}$, basal $90 \pm 5 \mathrm{pg} / \mathrm{ml}$; ${ }^{*} 625 \mathrm{pg} / \mathrm{ml}: 122 \pm 7 \mathrm{pg} / \mathrm{ml}$

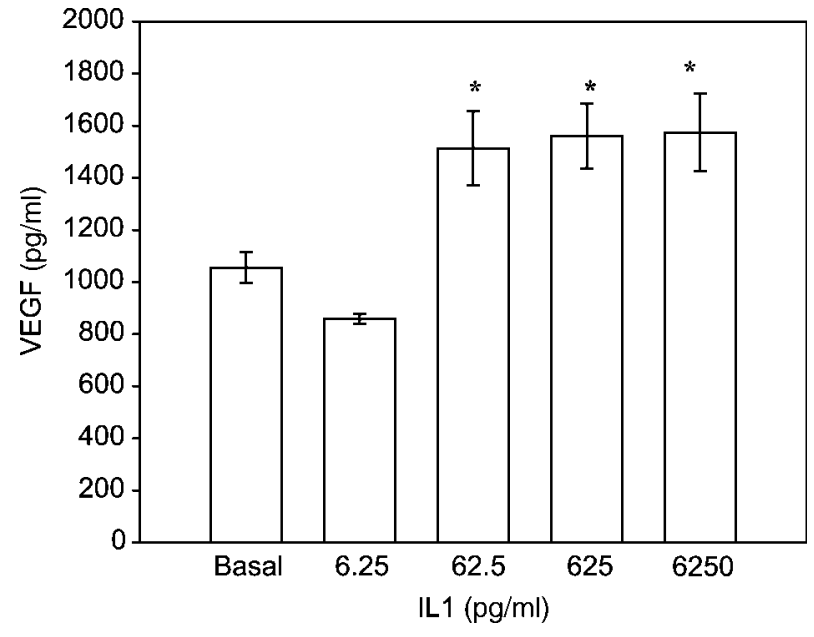

Figure 3 Stimulatory effect of IL $1 \alpha$ on VEGF secretion in HP75 cells (mean \pm S.E.M.; ${ }^{*} P<0.05$ compared to basal). 

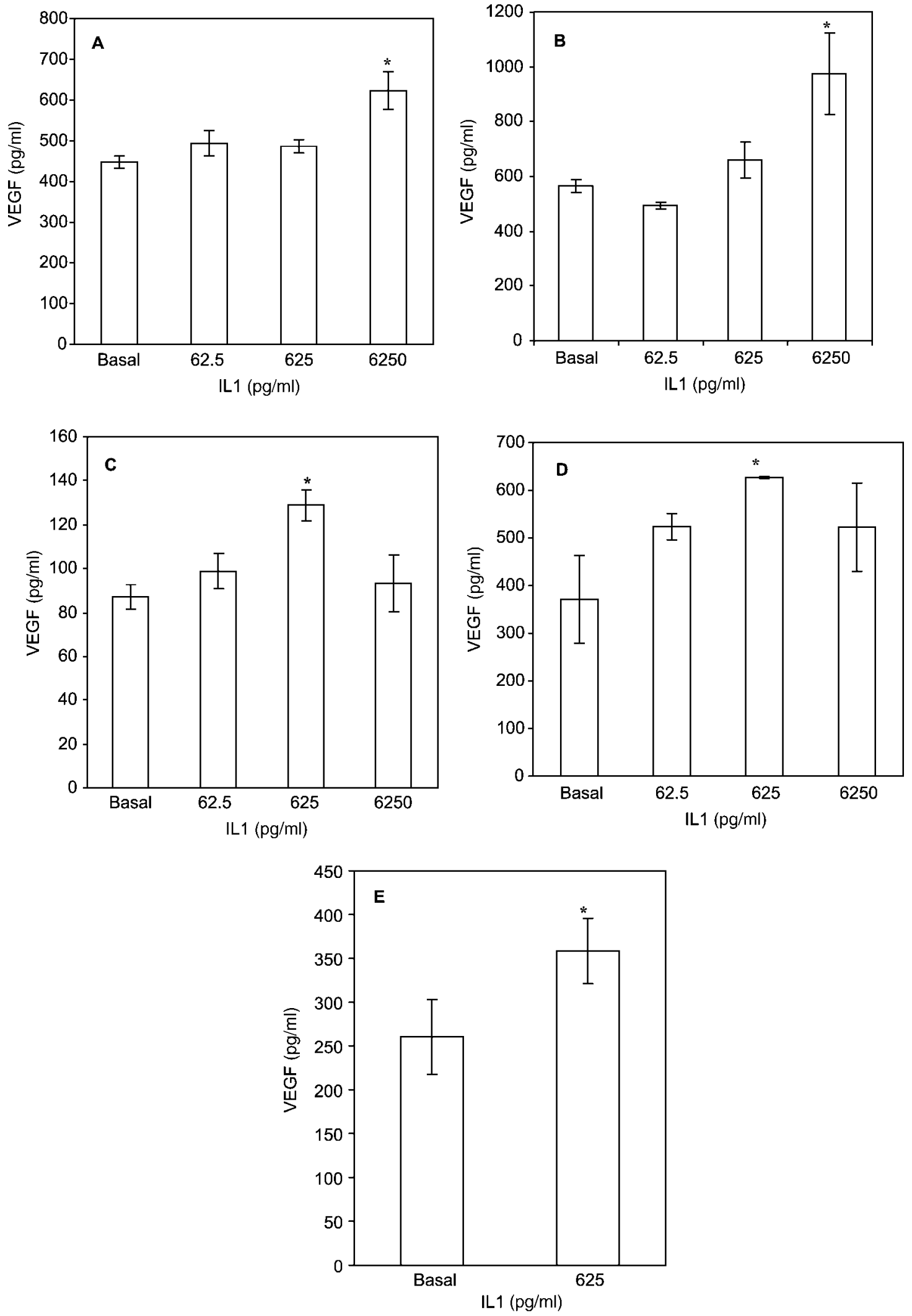

Figure 4 Effect of exogenous IL1 $\alpha$ on VEGF secretion in the following tumour types: (A) silent FSH/LH, (B) ACTH, (C) silent FSH/LH, (D) null cell and (E) GH (mean \pm S.E.M.; ${ }^{*} P<0.05$ ). 
(136\%), $\left.6250 \mathrm{pg} / \mathrm{ml}: 119 \pm 13 \mathrm{pg} / \mathrm{ml},{ }^{*} P<0.05\right)$. One tumour was treated with a single dose of IL1 $\alpha$ at $625 \mathrm{pg} / \mathrm{ml}$ only, and while we saw an increase in VEGF secretion, this was not significant (Fig. 4E, basal $260 \pm 43 \mathrm{pg} / \mathrm{ml} ; \quad 625 \mathrm{pg} / \mathrm{ml}: \quad 358 \pm 37 \mathrm{pg} / \mathrm{ml}$, $P=0.15)$.

\section{Effect of IL6 on VEGF secretion}

We investigated the effect of the addition of exogenous IL6 on the VEGF secretion from HP75 cells and cultured human pituitary tumour cells. Addition of IL6 at all doses used showed no effect on the level of VEGF secreted by HP75 cells (basal 940 $\pm 80 \mathrm{pg} / \mathrm{ml}$; IL6 $1 \mathrm{ng} / \mathrm{ml}$ : $762 \pm 129 \mathrm{pg} / \mathrm{ml}$, IL6 $10 \mathrm{ng} / \mathrm{ml}: 1078 \pm 85 \mathrm{pg} / \mathrm{ml}$, IL6 $100 \mathrm{ng} / \mathrm{ml}: 1006 \pm 93 \mathrm{pg} / \mathrm{ml}, P>0.05)$.

The effect of the addition of IL6 to primary cultures with five tumours was assessed. One ACTH-secreting tumour had no measurable levels of VEGF. Each of the other four tumours (one null, one $\mathrm{GH}$ and two silent FSH/LH) investigated showed no significant change in the levels of VEGF secreted in response to addition of IL6 $(P>0.05)$.

\section{Effect of ILI $\alpha$ and IL6 neutralising antibodies on VEGF secretion}

HP7 5 cells were treated with either an IL6 or an IL1 $\alpha$ neutralising antibody $(\mathrm{Ab})$, and VEGF release was measured after $72 \mathrm{~h}$ of culture. No significant changes in VEGF production by these cells with either antibody were detected. The quantity of neutralising antibody used was calculated for the maximum dose to neutralise the average basal secretion of its cytokine by HP75 cells (IL6 Ab basal $1725 \pm 59 \mathrm{pg} / \mathrm{ml} ; 300 \mu \mathrm{g} / \mathrm{ml}: 1721 \pm 27 \mathrm{pg} / \mathrm{ml}$, $P=0.95$; IL1 $\alpha$ Ab basal $371 \pm 24 \mathrm{pg} / \mathrm{ml} ; 1000 \mathrm{ng} / \mathrm{ml}$ : $375 \pm 54 \mathrm{pg} / \mathrm{ml}, P=0.96)$.

\section{VEGF, tumour volume and invasive status}

We investigated whether or not the levels of secreted of VEGF were associated with tumour invasive grade and/or volume. The invasive tumours (grades 3 and 4) had a higher average basal secretion of VEGF than those of the non-invasive type (invasive $2054 \pm 1608 \mathrm{pg} / \mathrm{ml}$, $n=12 ; \quad$ non-invasive $\quad 608 \pm 143 \mathrm{pg} / \mathrm{ml}, \quad n=18$; $P=0.867$ ); however, this difference was not significant. We did not observe any significant association between tumour volume and VEGF secretion $(r=-0.104$, $n=22, P=0.46)$.

\section{Discussion}

The majority of human pituitary adenomas, independently of subtype, and HP75 cells synthesise and secrete VEGF in vitro. There is a strong correlation between both the amount of IL1 $\alpha$ and IL6 secreted and the VEGF produced by cultured adenoma cells.

In the normal pituitary gland, VEGF is synthesised and released only by FS cells $(45,46)$. Mouse and rat pituitary tumour cell lines (AtT/20. $\mathrm{GH}_{3}$ and AT3-1) and, it now seems, HP75 constitutively synthesise and release VEGF. FS cells are rarely found in human pituitary adenomas; the finding that the majority of these tumours produce VEGF suggests that the adenoma cells are the source. This further implies that tumour transformation results in the acquisition of the ability to produce this peptide.

VEGF has previously been shown to be present immunocytochemically in human pituitary adenomas. Lloyd et al. showed varying degrees of positivity with $93 \%$ of tumours from a large study $(n=148)(37)$. Lohrer et al. showed similar levels of VEGF expression with $93 \%$ of tumours positive (35). The slightly lower detection level in our study may be accounted for by the fact that our minimum detection limit for the VEGF assay was higher than that used by Lohrer et al. (20 vs $3 \mathrm{pg} / \mathrm{ml}$ ).

Tumour size is dependent on adequate vascularisation. In pituitary adenomas, we and others have not demonstrated a correlation between VEGF production and tumour volume (35). However, there is a tendency for invasive tumours to have higher production than non-invasive ones, although this did not approach statistical significance. The reasons for this may be that other factors, such as tissue architecture, are important.

Although there is a positive correlation between IL6 and VEGF produced by adenomas, exogenous IL6 had no acute effect on VEGF release. This was confirmed by the lack of effect of IL6 neutralising antibody on VEGF secretion. This, however, does not exclude a chronic effect of IL6 on VEGF production and an effect which is dependent on the topographic relationship of cells in the undispersed tumour or the presence of hypoxia. This positive correlation of IL6 with VEGF has also been demonstrated in other tumours, such as breast and gastric malignancies $(31,32,34)$.

On the other hand, IL $1 \alpha$, which, as we have demonstrated here, has a positive correlation with VEGF, stimulated VEGF release by adenomas and HP75 cells in culture. However, the addition of neutralising antibody did not affect basal VEGF release.

The associations of IL6 and IL1 $\alpha$ with tumour volume suggest that the presence of these cytokines confers a growth advantage on the tumour, allowing its increased expansion. While we found no direct relationship between VEGF and tumour volume, it is more likely there is an indirect link between the two. VEGF is required for neovascularisation and may create favourable conditions for increased growth, but it is likely that other factors are required for tumour enlargement or inhibiting increased growth. Turner et al. observed that microprolactinomas are significantly less vascular than macroprolactinomas, 
although they did not observe this relationship in GHsecreting tumours (47). Along with its association with VEGF, IL6 is likely to have other roles in the pathogenesis of these tumours. We know that the presence of IL6 is positively associated with pituitary tumour invasiveness $(48,49)$, and driving increased vascularisation would facilitate this process.

We do not know whether the increase in VEGF levels seen in response to exogenous IL1 $\alpha$ in both the cell-line and primary cultures is controlled by the same mechanism as autocrine stimulation. Nor do we know whether the association between basal IL1 $\alpha$ and VEGF requires IL6. However, we have already shown that basal IL1 $\alpha$ and IL6 secretions are significantly and positively associated (SA Borg, KE Kery, JA Royds, RD Battersby and TH Jones, unpublished observations). FS cells are a potential source of IL $1 \alpha$, and while they are known to secrete IL6, it has not been reported that they secrete IL $1 \alpha$. FS cells are uncommon within an adenoma, and it has been observed that a transition zone rich in FS cells exists between the adenoma and normal tissue $(50,51)$. Lohrer et al. (35) proposed that in addition to any other effects IL6 may have, it may enhance the release of VEGF from FS cells in the transition zone, further increasing levels of VEGF in the region.

In conclusion, we have shown that human pituitary tumours, independently of subtype, and HP75 cells constitutively secrete VEGF in vitro. There is a strong positive correlation between basal production of IL6, IL1 $\alpha$ and VEGF. Furthermore, exogenous IL1 $\alpha$ stimulates VEGF production in vitro. These findings demonstrate that cytokine production is closely linked to VEGF release. The mechanism of this association is not clear, as VEGF is not associated with tumour volume or invasive status. However, since IL6 is a marker of invasiveness and IL6 secretion was found here to be associated with tumour volume, it would be reasonable to assume that VEGF is required for vascularisation of the tumour under these circumstances, and that would explain the relationship of these cytokines to VEGF.

\section{Acknowledgements}

We thank Dr T Powell for his expertise in examining the MRI scans measured for this study. This project has been supported by the Yorkshire Cancer Research.

\section{References}

1 Ferrara N. Vascular endothelial growth factor and the regulation of angiogenesis. Recent Progress in Hormone Research 20005515.

2 Folkman J \& Shing Y. Angiogenesis. Journal of Biological Chemistry $199226710931-10934$.

3 Folkman J. What is the evidence that tumors are angiogenesis dependent? Journal of the National Cancer Institute 1990 82 4-6.

4 Carmeliet P, Ferreira V, Breier G, Pollefeyt S, Kieckens L, Gertsenstein M, Fahrig M, Vandenhoeck A, Harpal K, Eberhardt C, Declercq C, Pawling J, Moons L, Collen D, Risau W \& Nagy A.
Abnormal blood vessel development and lethality in embryos lacking a single VEGF allele. Nature $1996 \mathbf{3 8 0} 435-439$.

5 Ferrara N, Carver-Moore K, Chen H, Dowd M, Lu L, O'Shea KS, Powell-Braxton L, Hillan KJ \& Moore MW. Heterozygous embryonic lethality induced by targeted inactivation of the VEGF gene. Nature 1996380 439-442.

6 Jones TH, Justice S, Price A \& Chapman K. Interleukin-6 secreting human pituitary adenomas. Journal of Clinical Endocrinology and Metabolism 199173 207-209.

7 Jones TH, Daniels M, James RA, Justice SK, McCorkle R, Price A, Kendall-Taylor P \& Weetman AP. Production of bioactive and immunoreactive interleukin-6 (IL6) and expression of IL6 messenger ribonucleic acid by human pituitary adenomas. Journal of Clinical Endocrinology and Metabolism $1994 \mathbf{7 8} 180-187$.

8 Green VL, Atkin SL, Speirs V, Jeffreys RV, Landolt AM, Mathew B, Hipkins L \& White MC. Cytokine expression in human anterior pituitary adenomas. Clinical Endocrinology $199645179-185$.

9 Vankelecom H, Carmeliet P, Van Damme J, Billiau A \& Denef C. Production of interleukin- 6 by folliculo-stellate cells of the anterior pituitary gland in a histiotypic cell aggregate culture system. Neuroendocrinology 198949 102-106.

10 Ueta TY, Levy A, Chowdrey HS \& Lightman SL. S-100 antigenpositive folliculo-stellate cells are not the source of IL6 gene expression in human pituitary adenomas. Journal of Neuroendocrinology $19957467-474$.

11 Jin L, Kulig E, Qian X, Scheithauer BW, Eberhadt NL \& Lloyd RV. A human pituitary adenoma cell line proliferates and maintains some differentiated functions following expression of SV40 large T-antigen. Endocrine Pathology 19989 169-184.

12 Detmar M. Tumor angiogenesis. Journal of Investigative Dermatology Symposium Proceedings 20005 20-23.

13 Brown LF, Detmar M, Claffey K, Nagy JA, Feng D, Dvorak AM \& Dvorak HF. Vascular permeability factor/vascular endothelial growth factor: a multifunctional angiogenic cytokine. EXS $199779233-269$.

14 Dvorak HF, Brown LF, Detmar M \& Dvorak AM. Vascular permeability factor/vascular endothelial growth factor, microvascular hyperpermeability and angiogenesis. American Journal of Pathology 1995146 1029-1039.

15 Volm M, Koomagi R, Mattern J \& Stammler G. Coexpression of VEGF and bFGF in human epidermoid lung carcinoma is associated with increased vessel density. Anticancer Research $1997 \mathbf{1 7}$ 99-103.

16 Brown LF, Berse B, Jackman RW, Tognazzi K, Guidi AJ, Dvorak HF, Senger DR, Connolly JL \& Schnitt SJ. Expression of vascular permeability factor (vascular endothelial growth factor) and its receptors in breast cancer. Human Pathology 199526 86-91.

17 Olson TA, Mohanraj D, Carson LF \& Ramakrishnan S. Vascular permeability factor gene expression in normal and neoplastic human ovaries. Cancer Research 199454 276-280.

18 Plate KH, Breier G, Weich HA \& Risau W. Vascular endothelial growth factor is a potential tumour angiogenesis factor in human gliomas in vivo. Nature 1992359 845-848.

19 Hashimoto E, Ogita T, Nakaoka T, Matsuoka R, Takao A \& Kira Y. Rapid induction of vascular endothelial growth factor expression by transient ischemia in rat heart. American Journal of Physiology 1994267 H1948-H1954.

20 Minchenko A, Bauer T, Salceda S \& Caro J. Hypoxic stimulation of vascular endothelial growth factor expression in vitro and in vivo. Laboratory Investigation $199471374-379$.

21 Ben-Av P, Crofford LJ, Wilder RL \& Hla T. Induction of vascular endothelial growth factor expression in synovial fibroblasts by prostaglandin E and interleukin-1: a potential mechanism for inflammatory angiogenesis. FEBS Letters 1995372 83-87.

22 Salven P, Hattori K, Heissig B \& Rafii S. Interleukin- $1 \alpha$ promotes angiogenesis in vivo via VEGFR-2 pathway by inducing inflammatory cell VEGF synthesis and secretion. FASEB Journal 2002 $161471-1473$.

23 Jung YD, Liu W, Reinmuth N, Ahmad SA, Fan F, Gallick GE \& Ellis LM. Vascular endothelial growth factor is upregulated by 
interleukin-1 beta in human vascular smooth muscle cells via the p38 mitogen-activated protein kinase pathway. Angiogenesis 2001 4 155-162.

24 Tanaka T, Kanai H, Sekiguchi K, Aihara Y, Yokoyama T, Arai M, Kanda T, Nagai R \& Kurabayashi M. Induction of VEGF gene transcription by IL-1 beta is mediated through stress activated MAP kinases and Sp1 sites in cardiac myocytes. Journal of Molecular and Cellular Cardiology 200032 1955-1967.

25 Levitas E, Chamoun D, Udoff LC, Ando M, Resnick CE \& Adashi EY. Periovulatory and interleukin-1 $\beta$-dependent up-regulation of intraovarian vascular endothelial growth factor (VEGF) in the rat: potential role for VEGF in the promotion of perivulatory angiogenesis and vascular permeability. Journal of the Society for Gynecological Investigation $2000751-60$.

26 Barker JN, Mitra RS, Griffiths CE, Dixit VM \& Nickoloff BJ. Keratinocytes as initiators of inflammation. Lancet 1991337 211-214.

27 Hirano T, Akira S, Taga T \& Kishimoto T. Biological and clinical aspects of interleukin-6. Immunology Today 199011 443-449.

28 Cohen T, Nahari D, Cerem LW, Neufeld G \& Levi B-Z. Interleukin 6 induces the expression of vascular endothelial growth factor. Journal of Biological Chemistry 1996271 736-741.

29 Wei L-H, Kuo M-L, Chen C-A, Cheng W-F, Cheng S-P, Hsieh F-J \& Hsieh C-Y. Interleukin-6 in cervical cancer: the relationship with vascular endothelial growth factor. Gynecologic Oncology 200182 49-56.

30 Salgado R, Benoy I, Weytjens R, Van Bockstaele DV, Van Marck E, Huget P, Hoylaerts M, Vermeulen PB \& Dirix LY. Aterio-venous gradients of IL-6, plasma and serum VEGF and D-dimers in human cancers. British Journal of Cancer 200287 1437-1444.

31 Salgado R, Vermeulen PB, Benoy I, Weyutjens R, Huget P, Van Marck E \& Dirix LY. Platelet number and interleukin-6 correlate with VEGF but not bFGF serum levels of advanced cancer patients. British Journal of Cancer $1999 \mathbf{8 0} 892-897$.

32 Huang S, Nagane M, Klingbeil CK, Lin H, Nishikawa R, Ji X-D, Huang C-H, Gill GN, Wiley HS \& Cavenee WK. The enhanced tumorigenic activity of a mutant epidermal growth factor receptor common in human cancers is mediated by threshold levels of constitutive tyrosine phosphorylation and unattenuated signalling. Journal of Biological Chemistry 1997272 2927-2935.

33 Benoy I, Salgado R, Colpaert C, Weytjens R, Vermeulen PB \& Dirix LY. Serum interleukin 6, plasma VEGF, serum VEGF, and VEGF platlet load in breast cancer patients. Clinical Breast Cancer 20022 311-315.

34 Huang SP, Wu MS, Wang HP, Yang CS, Yang CS, Kuo ML \& Lin JT. Correlation between serum levels of interleukin- 6 and vascular endothelial growth factor in gastric carcinoma. Journal of Gastroenterology and Hepatology 200217 1165-1169.

35 Lohrer P, Gloddek J, Hopfner U, Losa M, Uhl E, Pagotto U, Stalla GK \& Renner U. Vascular endothelial growth factor production and regulation in rodent and human pituitary tumour cells in vitro. Neuroendocrinology 2001 74 95-105.

36 Mccabe CJ, Boelaert K, Tannahill LA, Heaney AP, Stratford AL, Khaira JS, Hussain S, Sheppard MC, Franklyn JA \& Gittoes NJL. Vascular endothelial growth factor, its receptor KDR/Flk-1, and pituitary tumor transforming gene in pituitary tumors. Journal of Clinical Endocrinology and Metabolism $2002874238-4244$.

37 Lloyd RV, Scheithauer BW, Kuroki T, Vidal S, Kovacs K \& Stefaneanu L. Vascular endothelial growth factor (VEGF) expression in human pituitary adenomas. Endocrine Pathology $199910229-235$.

38 Renner U, Lohrer P, Schaaf L, Feirer M, Schmitt K, Onofri C, Arzt E \& Stalla GK. Transforming growth factor- $\beta$ stimulates vascular endothelial growth factor production by folliculostellate pituitary cells. Endocrinology 2002143 3759-3765.

39 Gloddek J, Pagotto U, Paez Pereda M, Arzt E, Stalla GK \& Renner U. Pituitary adenylate cyclase-activating polypeptide, interleukin-6 and glucocorticoids regulate the release of vascular endothelial growth factor in pituitary folliculostellate cells. Journal of Endocrinology $1999 \mathbf{1 6 0} 483-490$.

40 Schechter J, Goldsmith P, Wilson C \& Weiner R. Morphological evidence for the presence of arteries in human prolactinomas. Journal of Clinical Endocrinology and Metabolism $1988 \mathbf{6 7}$ 713-719.

41 Elias KA \& Weiner RI. Direct arterial vascularization of estrogeninduced prolactin-secreting anterior pituitary adenomas. Proceedings of the Indian Academy of Sciences - Chemical Sciences $1984 \mathbf{8 1}$ 4549-4553.

42 Borg SA, Kerry KE, Baxter L, Royds JA \& Jones TH. Expression of interleukin-6 and its effects on growth of HP75 pituitary tumour cells. Journal of Clinical Endocrinology and Metabolism $2003 \mathbf{8 8} 4938-4944$.

43 Atkin SL, Hipkin L, Radcliffe J \& White MC. Hypotonic lysis of red blood cell contamination from human anterior pituitary adenoma cell preparations. In Vitro Cellular and Developmental Biology Animal 199531 657-658.

44 Hardy J. Transphenoidal Microsurgical Treatment of Pituitary Tumours. New York: Raven Press, 1979.

45 Jabbour HN, Boddy SC \& Lincoln GA. Pattern and localisation of expression of vascular endothelial growth factor and its receptor flt-1 in the ovine pituitary gland: expression is independent of hypothalamic control. Molecular and Cellular Endocrinology 1997 $13491-100$.

46 Ferrara N \& Henzel WJ. Pituitary follicular cells secrete a novel heparin binding growth factor specific for vascular endothelial cells. Biochemical and Biophysical Research Communications 1989 $161851-858$.

47 Turner HE, Nagy Z, Gatter KC, Esiri MM, Harris AL \& Wass JAH. Angiogenesis in pituitary adenomas and the normal pituitary gland. Journal of Clinical Endocrinology and Metabolism $2000 \mathbf{8 5}$ 1159-1162.

48 Gandour-Edwards R, Kapadia SB, Janecka IP, Martinez AJ \& Barnes L. Biological markers of invasive pituitary adenomas involving the sphenoid sinus. Modern Pathology 19958 160-164.

49 Suliman M, Borg S, Kerry K, Royds JA, Powell T, Cullen DR \& Jones TH. IL-6 is associated with pituitary tumour invasiveness. Endocrine Pathology 200112 244-245.

50 Marin F, Kovacs K, Stefaneanu L, Horvath E \& Cheng Z. S-100 protein immunopositivity in human non-tumorous hypophyses and pituitary adenomas. Endocrine Pathology 19923 28-38.

51 Farnoud MR, Kujas M, Derome P, Racadot J, Peillon F \& Li JY. Interactions between normal and tumoral tissues at the boundary of human anterior pituitary adenomas. Virchows Archiv 1994 $\mathbf{4 2 4} 75-82$.

Received 29 September 2004

Accepted 2 November 2004 